\title{
Mathematical model of growth of two purelines of Padjadjaran female quail aged 0 to 6 weeks
}

\author{
A.Anang, H. Indrijani and E. Sujana \\ Faculty of Animal Husbandry, Universitas Padjadjaran \\ Jl. Raya Bandung-Sumedang Km 21, Jatinangor-Sumedang - Indonesia \\ Corresponding E-mail : asep.anang@unpad.ac.id
}

Received November 14, 2016; Accepted January 24, 2017

\begin{abstract}
ABSTRAK
Penelitian telah dilaksanakan di Pusat Pembibitan Puyuh Universitas Padjadjaran. Puyuh betina warna hitam dan warna coklat masing-masing seratus ekor telah diamati mulai dari menetas sampai umur enam minggu. Empat model kurva pertumbuhan yang dibandingkan adalah Gompertz, Logistic, Richards, dan Morgan Mencer Flodine (MMF). Ketepatan model diukur dari koefisien determinasi ( $\left.{ }^{2}\right)$ dan salah baku dugaan (SE). Hasil penelitian menunjukan bahwa nilai $\mathrm{R}^{2}$ berkisar dari 0,9950 sampai dengan 0,9988 untuk puyuh warna hitam dan dari 0,9984 sampai dengan 0,9992 untuk puyuh warna coklat. Dugaan SE berkisar antara 1,99 g sampai 4,01 g untuk puyuh warna hitam dan 1,92 g sampai $2,52 \mathrm{~g}$ untuk puyuh warna coklat. Model Gompertz merupakan model yang terbaik dengan $\mathrm{R}^{2}$ dan $\mathrm{SE}$ masing-masing 0,9988 dan 1,99 g untuk puyuh warna hitam, dan 0,9991 and 1,92 g untuk puyuh warna coklat. Umur titik infleksi, maksimum pertambahan bobot badan dan bobot waktu infleksi adalah 4,18 minggu, 27,87 g dan 100,23 g untuk galur hitam, dan 3,38 minggu, 25,05 g, dan 75,34 g untuk galur coklat.
\end{abstract}

Kata kunci : puyuh betina, kurva pertumbuhan

\begin{abstract}
A research was conducted at Quail Breeding Centre of Padjadjaran University. A hundred quails of female black and brown color of each line was observed from hatch to age of six weeks. Four growth models were compared: Gompertz, Logistic, Richards, and MMF. The best fit was measured with Coefficient of determination $\left(\mathrm{R}^{2}\right)$ and standard error of prediction (se). The results showed that all observed models have high accuracy with $\mathrm{R}^{2}$ ranging from 0.9950 to 0.9988 for black color, and 0.9984 to 0.9992 for brown color respectively. Standard errors of prediction (SE) ranged from $1.99 \mathrm{~g}$ to $4.01 \mathrm{~g}$ for black, and from $1.92 \mathrm{~g}$ to $2.52 \mathrm{~g}$ for brown, respectively. Gompertz model was more favorable with $\mathrm{R}^{2}$ and SE of 0.9988 and $1.99 \mathrm{~g}$ for black, and 0.9991 and $1.92 \mathrm{~g}$ for brown, respectively. Age at inflection, maximum average daily gains and weights at inflection were 4.18 week, $27.87 \mathrm{~g}$ and $100.23 \mathrm{~g}$ for black line and 3.38 week, $25.05 \mathrm{~g}$ and $75.34 \mathrm{~g}$ for brown line, respectively.
\end{abstract}

Keywords : female quail, growth curve

\section{INTRODUCTION}

Quail or Coturnix Coturnix japonica or Japanese quail has a great potential to be developed in Indonesia. Population in the year 2011 was 7,356,648 birds, increased by
$12,234,188$ in 2012 . The population continued to increase to $12,552,974$ birds in $2013,12,692,213$ birds in 2014, and 12,903,759 birds in 2015 (Directorate General of Livestock and Animal Health, 2015). Quail is mostly reared for egg production with the production, which is able to 
reach 300 eggs per female per year. The animal plays an important role for egg diversification, which is still produced from laying hens.

Padjadjaran University through science and technology program for Creativity Innovation Campus (IbiKK), Directorate General of Higher Education, Ministry of Research and Higher Education, is developing two pure lines of laying quails with black and brown colors in separate pens. The quails were selected for egg production and egg weight. The development of two pure lines is to avoid inbreeding in the final stock and for auto-sexing, so the male and female in the final stock can be sexed directly on father color base.

Growth is a fundamental biological process and plays an important role in animal husbandry. Growth can be defined as an increase in the number and size of the cells (Sengul and Kiraz, 2005). When the animal grows, there will be changes in both the size of the animal, and organ itself, such as the gastrointestinal tract, heart, lungs, etc. Growth can easily be measured in live weight. An increase the size, the organs may also be increase. Growth relates with age, an increase in age, body weight will enlarge to a certain point of inflection, then growth gradually decrease and finally ceases.

Growth is of a importance thing in female laying quail as it relates to age at first age, egg weight, and management of husbandry. The quails whose lower weight at first egg will produce lower egg weight and lower persistency, thus weight target a long with age in female quail is essential.

Growth performs a curve and can be described with a model of mathematic. Many models have been published such a model Gompertz (Raji et al., 2014b), Logistic (France and Thornley, 1984), Richards (Richards, 1959), Brody (Brody, 1945), Bertalanffy (von Bertalanffy, 1957), and Morgan Mencer Flodine (MMF) (Sengul and Kiraz, 2005; Nerinc et al, 2010). The models are very specific for particular of animal, in which it might fit best in one animal, but might not fit to others. The purpose of this study was to find the best mathematical model of growth for pure two female pure lines of Padjadjaran quails at age of 0 to 6 weeks.

\section{MATERIALS AND METHODS}

Research was conducted at Quail Breeding
Center, Faculty of Animal Husbandry, Padjadjaran University. Hundred female birds of each pure line (black and brown colors) were reared in cages with dimension of $180 \times 100 \mathrm{~m}^{2}$. The birds were fed commercial fed with $22-24 \%$ protein and 2,900 kcal metabolizable energy. The feed was given twice a day. Body weight was measured every week (gram) from hatch to the age of 6 weeks, so there were seven measurements al together. Each bird was tagged individually. The models compared were Gompertz, Logistic, Morgan Mencer Flodine (MMF), and Richards. The observed models were commonly used in poultry. The Mathematical equations are presented in Table 1.

Table 1. Growth Model Equation

\begin{tabular}{ll}
\hline Models & $y=a e^{-e^{b-c x}}$ \\
Lompertz & $y=\frac{a}{\left(1+b e^{-c x}\right)}$ \\
MMF & $y=\frac{a}{\left(1+b e^{-c x}\right)}$ \\
Richards & $y=\frac{a}{\left(1+e^{b-c x}\right)^{1 / d}}$
\end{tabular}

where

$\mathrm{y}=$ Weight (gram)

$\mathrm{x}=$ Age (week)

$\mathrm{a}=$ Asymptotic or maximum growth response

$\mathrm{b}=$ Scale parameter related to initial weight

c $=$ Intrinsic growth rate

$\mathrm{d}=$ Shape parameters.

The accuracy of the models were indicated with the coefficient of determination $\left(\mathrm{R}^{2}\right)$, and standard error of prediction (SE). The formulas are as follows:

$$
\mathrm{R}^{2}=\frac{\text { sum of square of regression }}{\text { total sum of square }}
$$

and

$$
\mathrm{SE}=\sqrt{\text { mean square of error }}
$$

both sum of square and mean squares were obtained from analyses of variance. Higher $R^{2}$ and lower SE, the model is better. 
Weekly Predicted Average Daily Gains (ADG) from the best model were calculated to estimate the inflection point. The ADG was calculated with the following formula:

$$
\mathrm{ADG}=\frac{\mathrm{W}_{\mathrm{t}}-\mathrm{W}_{\mathrm{t}-1}}{\mathrm{t}-\mathrm{t}_{\mathrm{t}-1}}
$$

where

$\mathrm{ADG}=$ weekly Average Daily Gain

$\mathrm{W}=$ weight

$\mathrm{t}$ and $\mathrm{t}-1$ = interval time (weekly).

The weekly ADG was then fitted to quadratic regression model with the formula:

$$
\mathrm{y}=\mathrm{a}+\mathrm{bx}+\mathrm{cx}^{2}
$$

where: $y=$ weekly ADG, $x=$ age (week), and $a, b$, and $c$ were parameters of regression. The maximum of ADG or the age of inflection was then estimated by the first derivative of the regression. The age of inflection was then used to predict maximum ADG and the weight at inflection. The estimates were calculated by using software Curve Expert 1.4 (Hyams, 2010).

\section{RESULTS AND DISCUSSIONS}

Body weights from hatch to age of 6 week are presented in Table 2 and Figure 1. Table 2 and Figure 1 show that weights at hatching were 7.41 and 7.45 for black and brown colors, respectively. Brown color quail grew slower than black color at early age, but after age of four week, it grew faster than the brown. The weights at six week
Table 2. Body weight from hatch to age of six

\begin{tabular}{|c|c|c|}
\hline Age (Week) & Black & Brown \\
\hline & \multicolumn{2}{|c|}{ - } \\
\hline 0 & 7.45 & 7.41 \\
\hline 1 & 24.19 & 19.29 \\
\hline 2 & 46.79 & 36.62 \\
\hline 3 & 74.78 & 66.49 \\
\hline 4 & 93.41 & 91.13 \\
\hline 5 & 116.45 & 120.82 \\
\hline 6 & 131.51 & 141.22 \\
\hline
\end{tabular}
week

were $131.51 \mathrm{~g}$ for black and $141.22 \mathrm{~g}$ for brown, respectively.

Weights at hatching and at six week of padjadjaran pure line quails were higher than those reported by Raji et al. (2014a) and Raji et al. (2014b), that hatching weight and weight at six week were $5.55 \mathrm{~g}$ and $94.97 \mathrm{~g}$, while Sujana et al. (2012) reported that weight at seven week was $127 \mathrm{~g}$. These results were in the line with those reported by Balcioglu et al. (2015) that the hatching weight was $7.6 \mathrm{~g}$, while the weight at six week was heavier (167 g). Nerinc et al. (2010) and Sezer et al. (2005) studied quails selected for growth and the results showed that the weights at

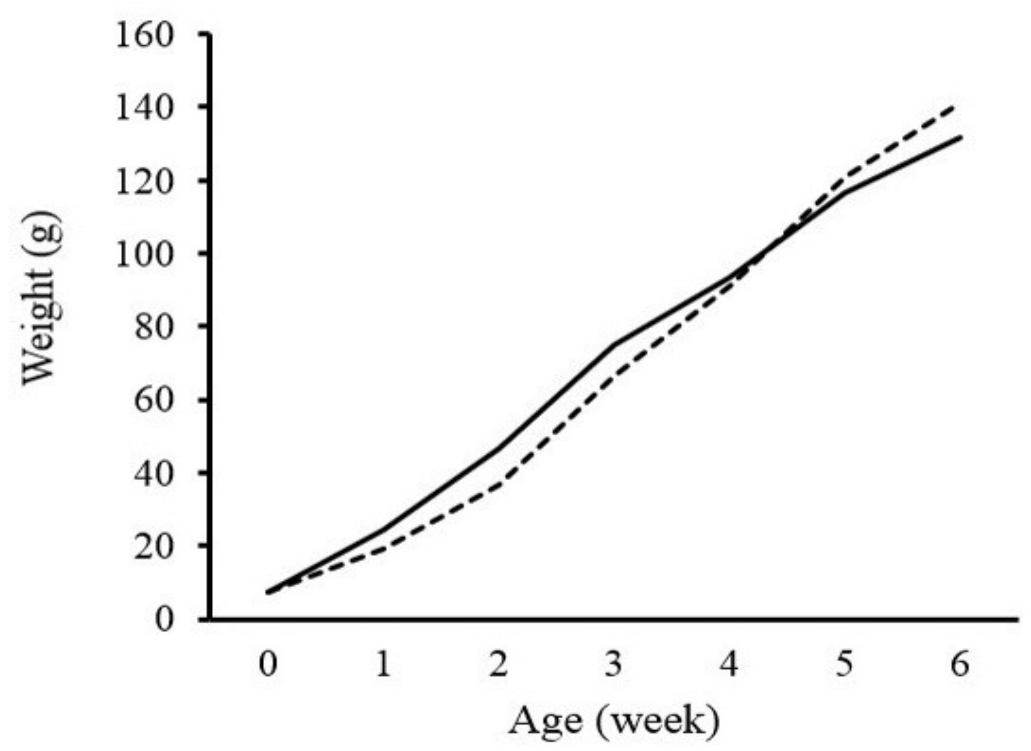

Figure 1. Weekly Body Weight . — : Black, -- -: Brown 
hatching and at six week were heavier, in which $8.53 \mathrm{~g}$, and $9.7 \mathrm{~g}$, respectively, while the weight at six week was $219 \mathrm{~g}$. Weight of quail is influenced by selection direction, whether the birds are selected for growth or egg production. Padjadjaran pure line quails were mainly selected for egg production, and the body weight might not change.

Mathematical model comparison is presented in Table 3. Based on the coefficient of determination $\left(\mathrm{R}^{2}\right)$, four observed models have high accuracy with $\mathrm{R}^{2}$ ranging from 0.9950 to 0.9988 for black color, and 0.9984 to 0.9992 for brown color respectively. Standard errors of prediction ranged from $1.99 \mathrm{~g}$ to $4.01 \mathrm{~g}$ for black, and from $1.92 \mathrm{~g}$ to $2.52 \mathrm{~g}$ for brown, respectively. Looking at standard error (SE), the Gompertz model is likely to be more consistent for both black and brown colors with $1.99 \mathrm{~g}$ and $1.92 \mathrm{~g}$, respectively. The Gompertz model is illustrated in Figure 2.

Comparison of the growth models in the Japanese quail have been studied by Sezer et al. (2005), Kizilkaya et al. (2006), Narinc et al. (2010), Gurcan et al. (2012), Emre et al. (2013),
Raji et al. (2014a), Raji et al. (2014b), and Balcioglu et al. (2015). The results showed that the models studied had high accuracy to estimate body weight of quail to six week of age.

Raji et al. (2014a; 2014b) studied three growth models, which were Weinbul, Richards, and Gompertz. The models had high accuracy in predicting weight with $\mathrm{R}^{2}=0.98$, but Gompertz was favorable to others. In meat quail, Richards model was sufficient to predictbody weight (Sezer, 2005). Balcioglu et al. (2015) observed growth models male and female of quail, and it was concluded that Gompertz model had a high accuracy with $\mathrm{R}^{2}=0.98$. Narinc et al., (2010) compared 10 growth models in quail, including Gompertz, Richards, logistics, Bertalanffy, Brody, Exponential, MMF, and three models of Hyperbolic. The result was concluded that the Gompertz model had the highest accuracy with $\mathrm{R}^{2}$ $=0.99998$. Moreover, that Gompertz model had an excellent fit with $\mathrm{R}^{2}$ of 0.999 in mice (Kunianto et al., 1998) and in rabbit with $\mathrm{R}^{2}$ of 0.999 (Setiaji et al., 2013).

Average daily gain (ADG) was calculated from predicted values resulting from Gompertz

Table 3. Growth Models Comparison

\begin{tabular}{|c|c|c|c|c|c|c|c|c|}
\hline & \multicolumn{4}{|c|}{ Black } & \multicolumn{4}{|c|}{ Brown } \\
\hline & Gompertz & Logistic & MMF & Richards & Gompertz & Logistic & MMF & Richards \\
\hline $\mathrm{a}$ & 164.47 & 141.15 & 7.57 & 155.58 & 213.43 & 162.87 & 8.23 & 190.66 \\
\hline b & 1.08 & 10.54 & 14.44 & -0.10 & 1.25 & 15.74 & 29.69 & 0.28 \\
\hline $\mathrm{c}$ & 0.43 & 0.79 & 255.91 & 0.51 & 0.36 & 0.77 & 289.38 & 0.47 \\
\hline d & - & - & 1.49 & 0.23 & - & - & 1.84 & 0.26 \\
\hline se & 1.99 & 4.01 & 1.98 & 2.80 & 1.92 & 2.52 & 2.36 & 2.02 \\
\hline $\mathrm{R}^{2}$ & 0.9988 & 0.9950 & 0.9991 & 0.9982 & 0.9991 & 0.9984 & 0.9989 & 0.9992 \\
\hline
\end{tabular}

Table 4. Point of Inflection

\begin{tabular}{cccccc}
\hline Line & $\begin{array}{c}\text { Quadratic Equation on } \\
\text { ADG }\end{array}$ & $\mathrm{R}^{2}$ & $\begin{array}{c}\text { Age at inflection } \\
(\text { weeks })\end{array}$ & $\begin{array}{c}\text { ADG at } \\
\text { Inflection (g) }\end{array}$ & $\begin{array}{c}\text { Weight at } \\
\text { inflection (g) }\end{array}$ \\
\hline Brown & $y=6.91+10.73 x-1.59 x^{2}$ & 0.958 & 3.38 & 25.05 & 75.34 \\
Black & $y=0.50+13.09 x-1.57 x^{2}$ & 0.997 & 4.18 & 27.87 & 100.23 \\
\hline
\end{tabular}




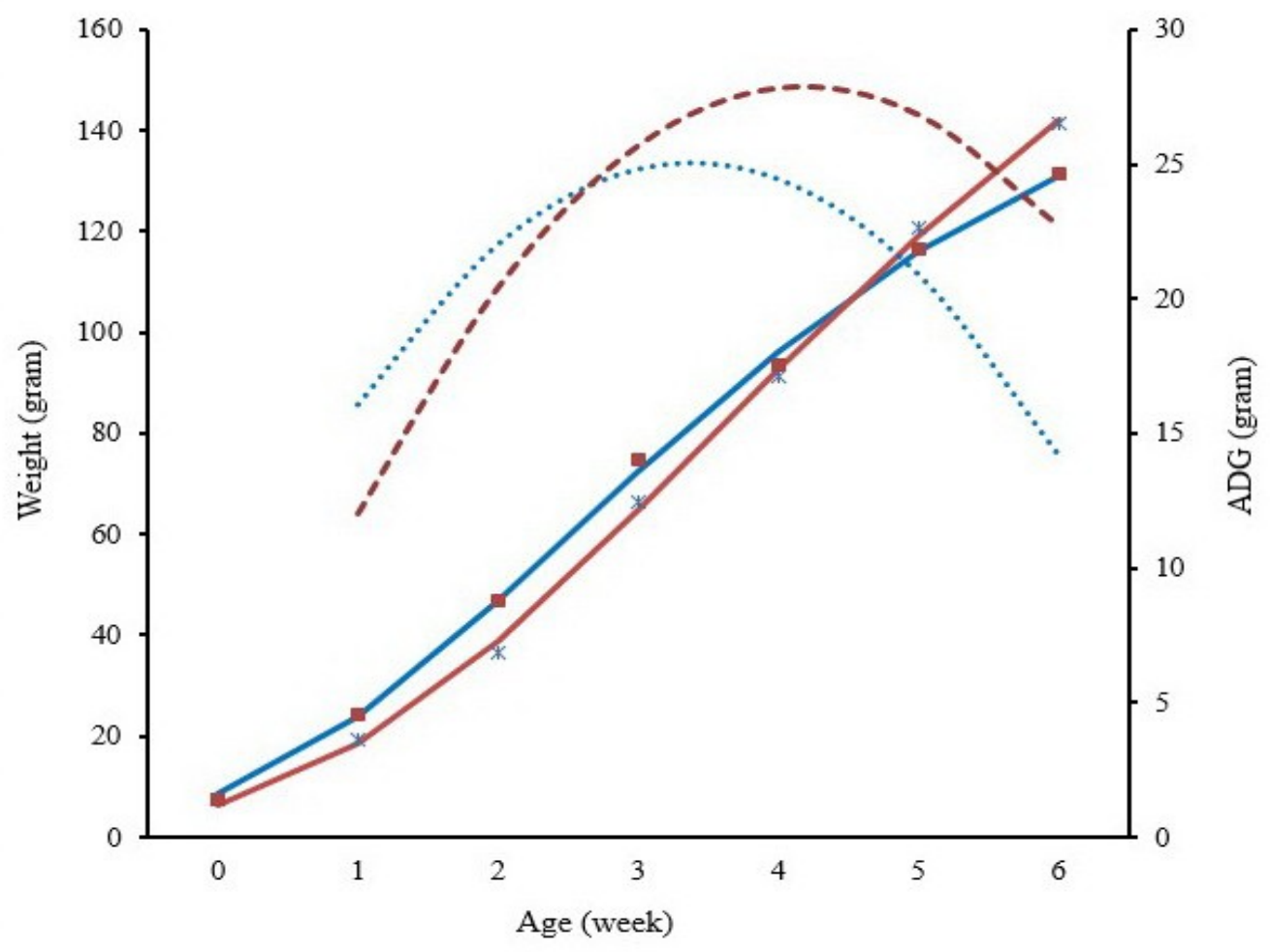

Figure 2. Gompertz Growth Model

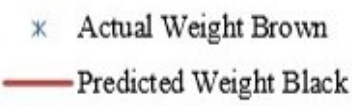

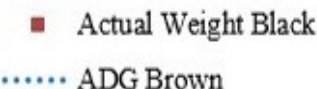

ADG Brown
- Predicted Weight Brown

ADG Black model, and the results are presented in Table 4 and figure 2. ADG increased to reach the peak, and then decreased gradually. The line pattern can be exactly described with quadratic model, which is indicated by high $\mathrm{R}^{2}$ for both lines. The Ages of inflection for black and brown lines were different; the black reached the peak at age of 4.18 weeks, while the brown was at age 3.38 weeks. The maximum ADGs and the weights of inflection were $27.87 \mathrm{~g}$ and $100.23 \mathrm{~g}$ for black line and $25.05 \mathrm{~g}$ and $75.34 \mathrm{~g}$ for brown line, respectively. The difference in the inflection was due to line characteristic differences, and there is lack of study in investigating the ADG and weight of inflection in quail.

\section{CONCLUSION}

Gompertz, logistics, MMF, and Richards models had a good accuracy to estimate body weight of pure line Padjadjaran quails of black and brown colors, but Gompertz model was more consistent and favorable. Age at inflection, maximum average daily gains and weights at inflection were 4.18 weeks, $27.87 \mathrm{~g}$ and $100.23 \mathrm{~g}$ for black line and 3.38 weeks, $25.05 \mathrm{~g}$ and $75.34 \mathrm{~g}$ for brown line, respectively.

\section{ACKNOWLEDGMENT}

The authors thank to Directorate General of Higher Education Ministry of Research and Higher Education trough Science and technology program for Creativity Innovation Campus (IbiKK) for financial support from 2014 to 2016.

\section{REFERENCES}

Balcıoğlu, M.S., K. Kızılkaya, H.İ. Yolcu and K. Karabağ. 2015. Analysis of growth characteristics in short-term divergently selected Japanese quail. South African J. Anim. Sci. 35:2.

Brody, S. 1945. Bioenergetics and Growth. New 
York: Reinhold. P. 491-661.

Hyams, D.G. 2010. Curve Expert Basic Release 1.4. http://docs.curveexpett.net/curve expert /basic/_static/CurveExpertBasic.pdf

Dirjen Peternakan dan Kesehatan Hewan. 2015. Populasi Puyuh Menurut Provinsi. (http://www.pertanian.go.id/ASEM2015NAK/Pop_Puyuh_Prop_2015.pdf)

France, J., and J. H.M. Thornley. 1984. Growth functions. In: Mathematical Models in Agriculture. J. France and J. H. M Thornley, ed. Butterworths, London. P. 7593

Gurcan, E.K., O. Cobanoglu and S. Genc. 2012. Determination of body weight-age relationship by non-linear models in Japanese quail. J. Anim. Vet. Adv. 11: 314317.

Karaman, E., D. Narinc, M. Z. Firat and T. Aksoy. 2013. Nonlinear mixed effects modeling of growth in Japanese quail. Poult. Sci. 92:1942-1948.

Kızılkaya, K., M.S. Balcığlu, H.İ. Yolcu, K. Karabag and I.H. Genc. 2006. Growth curve analysis using nonlinear mixed model in divergently selected Japanese quails. Arch. Geflügelk. 70 (4): 181-186.

Kunianto, E., A. Shinjo, and D. Suga. 1998. Analysis of growth in intersubspecific crossing of mice using Gompertz model. Asian-Aust. J. Anim. Sci. 11: 84-88.

Narinc, D., E. Karaman, M. Z. Firat and T. Aksoy. 2010. Comparison of non-linear growth models to describe the growth in Japanese quail. J. Anim. Vet. Adv. 9:1961-1966.

Raji, A.O. , S. T. Mbap and J. Aliyu. 2014a. Comparison of different models to describe growth of the Japanese quail (Coturnix japonica). Trakia J. Sci. 2:182-188.

Raji, A.O., N.K. Alade and H. Duwa. 2014b. Estimation of model parameters of the Japanese quail growth curve using Gompertz Model. Arch. Zootec. 63(243): 429-435.

Richards, F. J. 1959. A flexible growth function for empirical use. J. Exp. Bot. 10:290-300.

Sengul.T and S. Kiraz. 2005. Non-Linear models in large White Turkeys. Turk J. Vet. Anim. Sci. 29:331-337.

Setiaji, A., S. Sutopo and E. Kurnianto. 2013. Growth analysis in rabbit using Gompertz non-linear model. J. Indonesian Trop. Anim. Agric. 38: 92-97.

Sezer, M. and S. Tarhan. 2005. Model parameters of growth curves of three meat-typelines of Japanese quail. Czech J. Anim. Sci. 5 (1): 22-30.

Sujana, E., W. Tanwiryah and T. Widjastuti. 2012. Evaluation of quails (coturnix coturnix japonica) growth performance among the breeding centre of village communities in West Java. Lucrări Ştiinţifice-Seria Zootehnie. 58:70-72.

Von Bertalanffy, L. 1957. Quantitative laws formetabolism and growth. The Quarterly Review of Biology. 32: 217-231. 